\title{
Birth Order, Child Labor and School Attendance in Brazil
}

\author{
Patrick M. Emerson \\ Department of Economics \\ University of Colorado at Denver \\ Denver, Colorado 80217 \\ pemerson@carbon.cudenver.edu
}

\author{
André Portela Souza \\ Department of Economics \\ Vanderbilt University \\ Nashville, Tennessee 37235 \\ andre.souza@vanderbilt.edu
}

May 2002

\begin{abstract}
This paper examines the effects of birth order on the child labor incidence and school attendance of Brazilian children. Evidence from the psychology and sociology literature suggests that earlier-born children tend to have higher innate abilities. The economic implications of these findings are that earlier-born children may have more intra-household resources directed to them when they are young, and better outcomes as adults in areas such as education and earnings. However, in the context of child labor, the effects of birth order can be confounded by the fact that earlier born children are able to command higher wages than their younger siblings. Also, in the presence of capital constraints, poor families may not be able to afford to send their earlier born children to school, but may be able to send their later-born children due to the income earned by their older siblings. This paper presents both a theoretical discussion and an empirical investigation of the relationship between birth order and child labor. The results from the empirical investigation show that, in fact, male firstborn children are less likely to attend school than their later born siblings and that male last-born children are less likely to work as child laborers than their earlier born siblings. For female children, first-borns are less likely to go to school than their later born counterparts. These findings are intriguing as they run counter to the received wisdom of the effects of birth order, but make sense when considering the child labor decision of poor families in the face of capital constraints.
\end{abstract}

(JEL classification numbers: J20, O12, O54)

Keywords: Child Labor, School Attendance, Birth Order, Brazil.

Acknowledgements: For helpful comments and advice, we thank Katheryn Anderson, Laura Argys, Brian Duncan, Naci Mocan and seminar participants at Vanderbilt University and the University of Colorado at Denver. 


\section{Birth Order, Child Labor and School Attendance in Brazil}

Economists have become increasingly aware of the role that birth order plays in the intra-household investments in, and outcomes of, children. This awareness was prompted by the findings of psychologists and sociologists (e.g. Zajonc, 1976; Zajonc and Markus, 1975) that suggest that birth order has significant impacts on children's innate abilities and endowments, for example, on intelligence. Specifically, the near-consensus is that first-born children have higher IQ's and cognitive abilities than their later-born siblings. A number of previous economic studies have focused on either the outcomes of children as a function of birth order (e.g., Birdsall (1991), Kessler (1991) and Behrman and Taubman (1986)) or on the intra-household allocation of resources to children as a function of birth order (e.g., Behrman, (1988) and Horton (1988)). In both cases, the implication from the psychological and sociological literature is that outcomes and investments will be higher for earlier born children. This is because children with higher endowments of innate abilities should both fare better in school and subsequently in the adult labor market. Higher ability children may also have a greater amount of resources directed toward them by families who are inclined to invest in children with the highest potential return. The bulk of the evidence from the received literature points to significant birth order effects in both outcomes and allocations, although a few studies have failed to find significant effects (e.g. Kessler (1991)). The outcome studies have focused mainly on the U.S., while the allocation studies have focused mainly on developing countries. What this paper argues is that it is reasonable to expect birth order effects to be opposite when families are forced by poverty and capital constraints to send some or all of their children to work in the labor market. 
The proposition that birth order effects may be different in the child labor context stems from the recent child labor literature, starting with Basu and Van (1998), which emphasizes the fact that child labor is most frequently a result of familial poverty, which forces parents to send their children to the labor market. ${ }^{1}$ If this is an accurate description, then there may be a number of factors that determine which children a family chooses to send to the labor market and which children they choose to keep in school. Birth order is potentially one of these factors. The fact that earlier born children may have higher innate abilities may mean that their return to education is greater than that of later born children which might lead to the decision to withhold them from the labor market. This would be consistent with the previous literature on birth order effects. On the other hand, these same abilities may mean that they are able to command higher wages as children on the labor market than their later born siblings and thus are more likely to be sent to work as children. Also, older children can command higher wages than younger children, this also could lead to earlier born children being sent to work rather than their later born siblings. As working as a child laborer has a negative effect on educational achievement and adult wages (see Emerson and Portela Souza, 2002), these last two implications are in contrast to the earlier work in birth order that suggests that earlier born children are likely to have better outcomes than later born children. Thus, when examined in a developing country context, where child labor is widespread, the effects of birth order may be distinctly different than has been previously assumed.

One of the challenges to all studies of birth order, including the present study, is disentangling the effects of family size. Family size has been found to have negative developmental effects likely due to the fact that family resources are spread more thinly the

\footnotetext{
${ }^{1}$ See also Basu, 1999, 2001; Baland and Robinson, 2000; Emerson and Portela Souza, 2001.
} 
larger the family (see, e.g., Hanushek, 1992; Becker and Tomes, 1976; and Becker and Lewis 1973). The size of the family may also be an important factor in the labor force participation and school attendance of children. It may be that larger families increase the likelihood of the household being impoverished and thus large families are more likely to need the additional income a child who works in the labor market can provide. Or it may be that families increase the number of children they bear as a response to poverty so that the family's income may be supplemented by sending some children to work or having them provide labor within the household (or family farm). Either way, the additional income brought in by their offspring may allow families to invest in select children's education. This selection may depend on both the size of the family and the birth order of the child.

This paper builds a model of the birth order and child labor choice and examines the implications of this model empirically using household survey data from Brazil. ${ }^{2}$ Due to the fact that older children have higher earnings abilities, it is shown that it is just as reasonable to expect that earlier born children are more likely to work (and less likely to go to school) than are later born children as it is to expect the opposite. Thus, how birth order affects the child labor incidence and schooling of children in developing countries is an empirical issue.

The empirical findings show that sons who are the first-born in their families are more likely to work and less likely to go to school than later born sons, while daughters who are the first-born are less likely to go to school than later born daughters. These results hold when controlling for family size, looking only at completed families and looking only at completed families of a certain size. These results suggest that in developing countries

\footnotetext{
${ }^{2}$ Empirical studies of child labor have emphasized distinct dimensions of child labor such as poverty, family size, parent's bargaining power or social norms on the child's time allocation decisions (e.g., Emerson and Portela Souza, 2002, 2001; Freije and Lopez-Calva, 2001; Lopez-Calva, 2001; Grotaert and Patrinos, 1999). However, the empirical relation between birth order, child labor, and school attendance has not been explored.
} 
where child labor is widespread, birth order effects on children's outcomes may be opposite those in developed countries.

The paper proceeds as follows. The model of child labor and birth order is presented in Section II. The data used in the empirical investigation is discussed in Section III. The results of the empirical investigation are presented in Section IV. A discussion of the results and their implications is presented in the concluding section, Section V.

\section{A Model of Birth Order and Child Labor}

One well established finding in studies of child labor is that the older the child, the higher his or her wage. ${ }^{3}$ Older children are presumably more productive, more reliable and better able to perform more complex tasks. The fact that a child laborer's wage in the labor market is positively related to the child's age is an important factor in the effects of birthorder on the child labor and schooling decisions of a family. Specifically, if families send their children to work for subsistence reasons, they may choose to send their older children to the labor market first, where they can command relatively higher wages than their younger siblings. A simple model of a household's decision to send some children to work and others to school, that takes into account the fact that older children may have higher genetic endowments but may also command higher wages, is presented below.

It should be noted at the outset that here are other factors that can influence a family's decision to send a child to work that could be correlated with birth order, perhaps the most obvious being the sequence of births. For example, a poor family may wish to send their first-born to school but may not be able to do so due to financial constraints. Once that child is working, however, the income they he or she provides may allow the family to send the 
next child to school. The model we present below is static and abstracts from this consideration in order to present as simple a model as possible with which to illustrate the point that net birth order effects are indeterminate in the child labor context. A multiple period model would, in our opinion, illustrate the same point but with an unnecessary amount of complication.

Consider a framework similar to the unitary family model a là Becker (1982) where households consist of one adult (or two parents with a single utility function) and several children where fertility decisions are exogenous. ${ }^{4}$ The adult values the family's current consumption and each child's human capital attainment. The children in the household can go to school full-time, go to work in the labor market full-time, or spend some time in both activities. Children who work do not attain as much education as those who do not. The amount of schooling a child receives determines his or her wage as an adult. Therefore, the amount of labor income the adults bring into the household depends on how much schooling they received as children. Thus parents who were child laborers command lower wages and are more likely to demand their children work to supplement the family income. ${ }^{5}$

Consider a general household's utility maximization problem:

$$
\max U\left(c, h_{1}, \ldots, h_{J}\right)
$$

Subject to the budget constraint:

$$
c \leq w_{a}+\sum_{j}\left(1-e_{j}\right) w_{j}
$$

Where $U$ is the household's strictly concave utility function, $c$ is the total consumption of the household, $h_{j}$ is the child's $j$ human capital attainment when he or she reaches adulthood, $w_{a}$

\footnotetext{
${ }^{3}$ This is true of the children in our data set as well as others, see, for example Freije and Lopez-Calva (2001).

${ }^{4}$ Fertility decisions are, quite clearly, not exogenous, but assuming exogeneity for the mo ment is not critical for the main results of the model and keeps the analysis simple.
} 
is the adult's wage, $w_{j}$ is child $j$ 's wage, and $e_{j}$ is child $j$ 's time spent in school. Without loss of generality we will label each child in the family, $j=1, \ldots, J$, according to their birth order. Therefore, child $1(j=1)$ will be the first-born child, child $2(j=2)$ the second-born and so on. We will also exclude to possibility of multiple birth pregnancies (i.e. no twins, triplets, etc.)

We assume each agent is endowed with one unit of time and adults supply labor inelastically. Thus, for child $j$, the time spent working is $1-e_{j}$. We also assume that the child's wage is an increasing function of child's age, $w_{j}=w\left(a_{j}\right) .{ }^{6}$ For simplicity we assume there is a continuum of children's wages where $\frac{\partial w\left(a_{j}\right)}{\partial a_{j}}>0$, for all $j$. Thus, within a family at any point in time, we know: $w\left(a_{1}\right)>w\left(a_{2}\right)>\cdots>w\left(a_{J}\right)$. For ease of exposition we assume that the adult's wage is given by the production function $w_{a}=h_{a}{ }^{7}$

Children's education is converted into adult human capital by the idiosyncratic technology:

$$
h_{j}=h_{j}\left(e_{j}\right), \forall j
$$

where $h_{j}(0)=1$, and $\frac{\partial h_{j}\left(e_{j}\right)}{\partial e_{j}}>0$, for all $e_{j} \in[0,1]$

This idiosyncratic technology reflects the different innate abilities that each child may have, which may be a function of birth order.

Additionally, we assume that utility is monotonically increasing in consumption, so non-satiation applies and that a capital market does not exist. With these assumptions in

\footnotetext{
${ }^{5}$ This is similar to the child labor trap model in Emerson and Portela Souza, 2002.

${ }^{6}$ We could also assume that this wage is a function of the child's human capital as well, which would make the birth order effect on wages indeterminate. As our goal is simply to show that birth order effects may be opposite that which is commonly expected, we choose to consider wages as a function of age only.

${ }^{7}$ This assumes, of course, that the wage rate is unaffected by the supply of skilled labor. This is a strong assumption but the essential results would not change if we made the wage a function of skilled labor supply.
} 
place, we can substitute the constraints into the objective function (1) and derive the household's problem:

$$
\max _{\left\{e_{1}, \ldots, e_{J}\right\}} U\left(h_{a}+\sum_{j}\left(1-e_{j}\right) w\left(a_{j}\right), h_{1}\left(e_{1}\right), \ldots, h_{J}\left(e_{J}\right)\right)
$$

If we assume an interior solution $\left(e_{j}>0\right.$, for all $\left.j\right)$, we can derive the first order conditions. ${ }^{8}$ For each child $j$, the first order condition is:

$$
\frac{\partial U}{\partial e_{j}}:(-1) \frac{\partial u}{\partial e_{j}} w\left(a_{j}\right)+\frac{\partial u}{\partial h_{j}} \frac{\partial h_{j}}{\partial e_{j}}=0
$$

Note that the first order condition representing the marginal utility of increasing child's $j$ schooling has two elements. The first one represents the loss on family's utility due to the foregone income of child $j$. The second one is the gain in utility due to the increase of human capital of the child, which the adult cares about.

Deriving the first order condition for each child, gives us a system of $J$ equations and $J$ unknowns. Assuming the utility function is well-behaved, the optimal solution to this problem is a vector of education levels for each child in the household that solve the $J$ first order conditions, $e^{*}=\left(e_{1} *, \ldots, e_{J}^{*}\right)$, where:

$$
e_{j}^{*}=e\left(h_{a}, w\left(a_{j}\right)\right)
$$

Of course, the child labor function is just $1-e^{*}$. Note that, ceteris paribus, the higher the adult's human capital, the lower the amount of time spent working for child $j$. Also, the older the child, the greater the amount of time spent working for child $j$.

\footnotetext{
${ }^{8}$ It is quite reasonable to expect corner solutions in this case, but as we want to illustrate the effects of the tradeoff between work and school on children with different birth orders, it is sufficient to show this trade-off at the margin.
} 
Now we turn to the birth-order effects on child labor within a family. The relative amount of schooling (or child labor) the family will allocate for each child is given by the condition:

$$
\frac{\left(\partial u / \partial e_{1}\right) w\left(a_{1}\right)}{\left(\partial u / \partial h_{1}\right)\left(\partial h_{1} / \partial e_{1}\right)}=\ldots=\frac{\left(\partial u / \partial e_{J}\right) w\left(a_{J}\right)}{\left(\partial u / \partial h_{J}\right)\left(\partial h_{J} / \partial e_{J}\right)}
$$

That is, the family allocates time spend in school across children such that the ratios of the marginal utility of the child's wage rate to the marginal utility of the child's marginal gain in human capital are equal for all children. In this case, the birth-order effect on child labor and school attendance will depend on the marginal effect of schooling on the human capital accumulation of the child, and will also depend on how additional human capital effects the adult's utility function. Depending on these effects, older children may be more or less likely to work in the labor market. This also shows that the age difference between siblings may also matter.

If the parental utility function is concave on child's human capital and child's human capital is concave on schooling, as assumed, and if both children have the same ability to generate human capital for all levels of schooling, $\partial h_{1} / \partial e_{1}=\partial h_{2} / \partial e_{2}$, then the family will allocate relatively more child labor and less schooling to the older child. On the other hand, if the older child has higher ability such that $\partial h_{1} / \partial e_{1}>\partial h_{2} / \partial e_{2}$ for all $e$, it may be the case that the family will invest relative more schooling to the oldest child and allocate relative more child labor to the younger one. In other words, the birth-order effect will depend on parental preferences, the children's human capital accumulation technology, and the difference in the wage rate. 
As an illustrative example, assume the utility function is additively separable in income and children's human capital and that each child faces the same human capital function that is concave in schooling. Thus the household's problem becomes:

$$
\max _{\left\{e_{1}, \ldots, e_{J}\right\}}\left(h_{a}+\sum_{j}\left(1-e_{j}\right) w\left(a_{j}\right)+\sum_{j} h\left(e_{j}\right)\right)
$$

Again, if we assume an interior solution for all $e_{j}$, the family will allocate schooling time to their children such that $\frac{w\left(a_{1}\right)}{\partial h / \partial e_{1}}=\ldots=\frac{w\left(a_{J}\right)}{\partial h / \partial e_{J}}$. Clearly under these assumptions the younger the child, the more likely to attend school (and less likely to work).

Since the net effect of birth order depends on the relative magnitudes of the different countervailing forces in the model, the actual effect is an empirical issue. If the gain from the higher wages commanded by older children outweigh the potentially relatively higher returns to schooling due to higher genetic endowments, then we should expect that earlier born children are more likely to work as child laborers and less likely to attend school than later born children. If the opposite is true than we should expect that later born children are more likely to work as child laborers and less likely to attend school than earlier born children.

We search for empirical regularities of birth order effects on child labor and school attendance in Section IV. First, however, we describe the data used in our analysis and our sample selection criteria in the next section. 


\section{Data Set and Sample Selection}

The data used in the empirical analysis come from the 1998 Pesquisa Nacional por Amostragem a Domicílio (PNAD) from Instituto Brasileiro de Geografia e Estatística (IBGE), the Brazilian census bureau. The PNAD is a yearly and nationally representative household survey similar to the Current Population Survey in the U.S. It covers close to one hundred thousand households and includes information on the demographic and labor market characteristics of the households. Unlike most other years, the 1998 PNAD includes information on the labor market activities of all children in a household who are at least five years of age.

Our sample consists of all sons and daughters who are between five and sixteen years of age and live in a two-parent family. Therefore, we exclude all children younger than five and older than sixteen as well as all children from single head families. ${ }^{9}$ We exclude older children because Brazilian legislation allows them to participate in the labor market but precludes sixteen year old children or younger to work in the labor market. Moreover, we exclude single head families since the decision to send children to the labor market may be fundamentally different for single head households than two-parent households. Our sample, therefore, consists of 32,213 sons and 30,365 daughters. The basic statistics are presented in Table A1 of the Appendix.

We will also use two alternative samples to check the robustness of the results. As the potential endogeneity of fertility decisions may bias the estimation of the birth order effects, we check the robustness of the results by first comparing children living in completed families only. For this purpose we use a sub-sample of all children belonging to families

\footnotetext{
${ }^{9}$ We also excluded families where the age difference between the oldest sibling and the youngest parent is fourteen or below.
} 
where their mothers are forty years old or older who are unlikely to still be making fertility decisions. However, past fertility decisions are related to current family size and may, in turn, be correlated with the time allocation decisions for the children. For this reason we also construct another sub-sample of all children from families where there are exactly three siblings. We choose three children families to provide an adequate sample size as the mean number of children in the data set is 3 , as well as to make the analysis of the first- and lastborn coefficients relative to second-born children, which is helpful. Finally, as parents from completed families with the same number of siblings are more likely to have faced similar constraints and/or have had a similar set of preferences, we construct a sub-sample that includes all children from families where their mothers are forty years old or older and where there are exactly three siblings.

\section{Empirical Results}

A child in our sample is assumed to allocate his or her time among many activities. Chief among these activities are working as child laborer in the labor market (including work done on the family farm) and attending school. A child is defined to be a laborer if he or she works strictly positive hours in the labor market. ${ }^{10}$ Table 1 presents the time allocation figures under this definition of child labor for male and female children, separately. Most of the children in the sample attend school and there is not much gender difference. More than 88 percent of male children attend school and more than 90 percent of female children go to school. However, a greater proportion of male children work in the labor market. Specifically, more than 14 percent of male children work in the labor market whereas less

\footnotetext{
${ }^{10}$ An alternate definition, where a child is considered to be a laborer only if he or she usually works more than 20 hours in a week was also used and yielded qualitatively the same results.
} 
than 8 percent of female children participate in the labor market. For both males and females that are child laborers, more than 80 percent attend school as well.

In order to capture the birth order effect on the time allocation of the children, we estimate a series of bivariate probit models of the child labor and school attendance decisions of households with at least one child in the age range of 5 to 16 years old. We start by using an unrestricted sample of all households with a child in this age range. We then restrict the sample to include only those households where the mother is 40 or over in an attempt to look at only completed families, or those families who are no longer making fertility decisions. In an attempt to compare families that are likely to have made the same fertility decision we also use a sample of families with exactly three children. Finally, we restrict the sample further to include only those families with mothers 40 or over and with exactly three children. The goal of this last restriction is to, first, condition on those that are likely to have completed their child-bearing and, second, minimize possible bias due to the potential endogeneity of family size in the previous two regressions.

The dependent variables in all regressions are a child labor indicator variable that equals one if a child works strictly positive hours in the labor market and a school attendance indicator variable that equals one if a child goes to school. We construct two birth order variables: The first is an indicator variable that equals one if the child is the first-born child in the family. The second is an indicator variable that equals one if the child is the last-born child in the family. ${ }^{11}$ We also construct a variable that equals the age difference between the observed child and the first-born in the family, and another that equals the age difference between the observed child and the last-born in the family, as the theoretical model suggests 
that age difference is likely a factor in the child labor decision of the household. ${ }^{12}$ In addition, we construct an indicator variable that equals one if the first-born child in the family is female as it may matter, for example, if a second-born male child's older sibling is male or female. Additional controls included are the child's age, the child's race, the father's and the mother's schooling, the father's and the mother's age and an indicator variable that equals one if the household is in a rural area. For the first two estimations, we include a variable that equals the number of children in the family. Finally, we estimate the birth order effects for sons and daughters separately as the work that male and female children are expected to do as well as their duties within the household may be quite different.

Tables 2 through 5 present the birth order results for the unrestricted sample, the sample with only those households where the mother is 40 and over, the sample with all families with exactly three children, and the sample for those households where the mother is 40 and over and that have exactly three children, respectively. In each table, the first and third columns present the coefficients for child labor and school attendance for male children, and the fifth and seventh columns show the results for child labor and school attendance for female children.

Table 2 presents the coefficient estimates for the unrestricted sample. For male children, those that were born last are less likely to work, and those that were born first are less likely to go to school. For females, first-born children are less likely to attend school, but no more or less likely to work than their middle-born counterparts. Note that we are controlling for the age of the child so it is not age difference between observations that is

\footnotetext{
${ }^{11}$ To be precis e, the first-born and last-born indicator variables refer to the oldest and youngest children living in the same household at the time of the survey since the information in the PNAD on family composition are obtained from those living in the same household.

12 One of these will equal zero if the child happens to be the first- or last-born child in the family.
} 
driving these results. The indicator for the oldest child being female is positive and significant for the male schooling equation. The child's age and the education of the father and mother are all significant as are the rural and non-white (except for male school) indicator variables. The age of the father has no effect on any of the categories and the age of the mother is negative and significant for the male child's propensity to work. Note that the family size variable is highly significant for all categories and the results are consistent: a larger family means a higher probability to work and lower probability to go to school for both male and female children.

When the sample is restricted to include only those with mothers who are 40 years old or older, the main results, presented in Table 3, are unchanged. Note also that the nonwhite indicator variable is no longer significant in any category. The female oldest child indicator variable is now positive and significant for the female schooling equation. The age of the mother is now no longer significant for the male work equation. Another interesting difference is that the family size variable is no longer significant for the male and female work equations.

When the sample is restricted to include only those families with exactly three children, the main results, presented in Table 4, are again the same as in Table 2, except for the coefficient on first-born male's school attendance, which is still negative but no longer significant. Note that again, the non-white indicator variable is no longer significant in any category. The female oldest child indicator variable is now not significant for the male schooling equation. The age of the mother is again no longer significant for the male work equation but is positive and significant for the male school attendance equation. 
Finally, Table 5 presents the coefficient estimates for the sample restricted to just those families where the mother is 40 years old or older and who have exactly 3 children. This last restriction is, again, to minimize possible bias due to the potential endogeneity of the family size variable in the previous two regression estimations. In this case, last-born male children are still less likely to work than are their first- and middle-born siblings, but first-born male children are, as in Table 4, no less likely to attend school. Also, in contrast with the previous results, first-born females are now no less likely to attend school, although the coefficient is still negative. The loss of the significance in the estimation of the first-born coefficients is not surprising considering the way the sample is restricted, this leaves us with very few first-born children that we observe (i.e. in the 5 to 16 age range). In other words, by restricting the age of mothers to 40 years old and older, most first-borns in these families are older than 16 and thus do not enter the sample.

The next two tables, Tables 6 and 7, present the estimation results of two more models in an attempt to capture the effect of age difference. In the first estimation, we include the two age difference variables and drop the first- and last-born child indicators. In the second we include the average spacing among children in a family. We do the first estimation without first- and last-born indicator variables as there is, by construction, a direct correlation with the age difference variables. In both cases we present the results using the full sample, but results that are consistent with those presented in Tables 2 through 4 were obtained as well and are available upon request.

Table 6 presents the coefficient estimates for the model with only the age difference variables. Here, the age difference with the first-born child is significant for males but not for females in the work equation. The age difference with the last-born child is positive and 
significant for the male work equation and negative and significant for the male and female school equations. This means that for male children, the greater the age difference with the last-born, the more likely to work he is. Also, the greater the age difference with the lastborn the less likely to go to school he is. For females, the greater the age difference with the last-born, the less likely to go to school she is. Both of these results are consistent with the results in Table 2. The rest of the results are similar to those in Table 2 as well.

In order to estimate birth order effects while taking into account the average time between sibling births, one last model is estimated. In this case the unrestricted sample is used, and both the birth order indicator variables are included, along with a variable, average spacing, that is the average number of interval years among siblings. For instance, a family with three children aged 9,11 , and 13 years old would have the average spacing variable equal to 2 years. This variable is included as an attempt to control for age difference as distinct from birth order. The results are presented in Table 7. The average spacing variable is not significant in any equation. More importantly, including the average spacing variable does not change the qualitative results presented in Table 2: first-born children are less likely to attend school and male last-born children are less likely to work.

We also estimated a model where the two age difference variables and the first- and last-born variables are included. However, due to the way the variables are constructed we cannot interpret the coefficients using the ceteris paribus assumption. Evaluating these results involves obtaining the predicted probability for representative children. We refer the reader to the appendix for a discussion of the methodology and the results of this examination. 


\section{Conclusion}

The one result that is robust throughout is that male last-born children are less likely to work than their first- and middle-born siblings. This is consistent with the model of birth order and child labor where, ceteris paribus, older children are sent to the labor market because they can command higher wages and younger children, who cannot command as high wages, are sent to school. This is true, apparently, even though earlier born children tend to have higher genetic endowments. This explanation is consistent with the complementary results that, in the first two regressions, male children who are first-borns are less likely to attend school.

As for female children, it appears that females who are first-borns are less likely to attend school and no more or less likely to work than their middle- or last-born siblings. This result is consistent with the explanation given above, and also with the common practice in Brazil, as in other developing countries, of keeping the oldest female children out of school and, instead, assisting the mother with housework and childcare (which is not considered working in the labor force in the PNAD).

These results suggest that there may be fundamental differences in the effects of birth order on children's outcomes depending on whether widespread child labor exists in a country, or at least if a family is forced to send one or more children to the labor market. Thus it may be reasonable to expect that the effects of birth order have an opposite effect on children in the developed world than on children from developing countries, especially those from poorer households. 


\section{Appendix}

Table A1 presents the basic statistics of the variables used. Table A2 presents the coefficient estimates of the regression where both the birth order indicator variables and the age difference variables are included. At first glance it may seem that some of these results are inconsistent with the results presented above, however we can no longer interpret the coefficients on the birth order indicator variables and the age difference variables in isolation. Due to the way the variables are constructed, the ceteris paribus assumption does not hold. For instance, a first-born child will always have a zero value for the age difference with respect to the oldest whereas a non-first-born child will always have strictly positive values. So, in order to interpret these results we obtained a series of predicted probabilities for two representative families: one with only sons and one with only daughters. In both cases the families are white, urban, have three children, and the mother and father are both 40 and have 5 years of schooling. We then varied the age difference between the first-born and last-born from 3 to 15 years in three-year increments. In Figures 1 through 4 we plot the predicted probabilities of working and attending school for fist and last-born children, first for the family with only sons (Figure 1 and 2) and next for family with only daughters (Figure 3 and 4). Both sets of charts reveal the same basic pattern: that there appears to be no real birth order effect when age difference is 3 years, but there appears to be a large a birth order effect for age differences of 6 years or more, and that the effect increases with age difference.

These results are consistent with our model. As for the direction of the effect of birth order, it is as expected: first-borns are more likely to work and less likely to attend school than are last-borns. 


\section{REFERENCES}

Baland, Jean-Marie, and James A. Robinson. (2000) “Is Child Labor Inefficient?,” Journal of Political Economy, 108:4, pp. 663-679.

Basu, Kaushik. (2001) “Gender and Say: A Model of Household Behavior with Endogenously-determined Balance of Power," Cornell University, mimeo. . (1999) “Child Labor: Cause, Consequence, and Cure,” Journal of Economic

Literature, 37:3, pp.1083-1119.

Basu, Kaushik, and Pham Hoang Van. (1998) “The Economics of Child Labor," American Economic Review, 88:3, pp. 412-427.

Becker, Gary. (1982) Treatise on the Family. (Cambridge, MA: Harvard University Press).

Becker, Gary S., and H. Gregg Lewis. (1973) "On the Interaction between the Quantity and Quality of Children,” Journal of Political Economy, 81:2, pp. S279-S288.

Becker, Gary S., and Nigel Tomes. (1976) “Child Endowments and the Quantity and Quality of Children," Journal of Political Economy, 84:4, pp. S143-S162.

Behrman, Jere R. (1988) “Nutrition, Health, Birth Order and Seasonality: Intrahousehold Allocation among Children in Rural India," Journal of Development Economics, 28:1, pp. 43-62.

Behrman, Jere R., and Paul Taubman. (1986) "Birth Order, Schooling, and Earnings," Journal of Labor Economics, 4:3, pp. S121-S145.

Birdsall, Nancy. (1991) "Birth Order Effects and Time Allocation,” in T. Paul Schultz, ed., Research in Population Economics, Vol. 7. (Greenwich, CT: JAI Press), pp. 191213. 
Emerson, Patrick and André Portela Souza. (2002) "Is There a Child Labor Trap? InterGenerational Persistence of Child labor in Brazil," forthcoming, Economic Development and Cultural Change.

---------. (2001) “Bargaining Over Sons and Daughters: Child Labor, School Attendance and Intra-household Gender Bias in Brazil," Vanderbilt University Department of Economics Working Paper.

Freije, Samuel, and Luis Felipe Lopez-Calva. (2001) "Child Labor, School Attendance, and Poverty in Mexico and Venezuela", Colegio de Mexico, mimeo.

Grootaert, Christiaan, and Harry Anthony Patrinos, eds. (1999) Policy Analysis of Child Labor: A Comparative Study. New York: St. Martin's Press.

Hanushek, Eric A. (1992) “The Trade-off between Child Quantity and Quality,” Journal of Political Economy, 100:1, pp. 84-117.

Horton, Susan. (1988) "Birth Order and Child Nutritional Status: Evidence from the Philippines," Economic Development and Cultural Change, 36:2, pp. 341-54.

Kessler, Daniel. (1991) "Birth Order, Family Size, and Achievement: Family Structure and Wage Determination," Journal of Labor Economics, 9:4, pp. 413-426.

Lopez-Calva, Luis Felipe (2001) “A Social Stigma Model of Child Labor”, El Colegio de Mexico, mimeo.

Zajonc, R. B. (1976) “Family Configuration and Intelligence," Science, 192 (April 16), pp. 227-236.

Zajonc, R. B. and Gregory B. Markus. (1975) "Birth Order and Intellectual Development," Psychological Review, 82 (January), pp. 74-88. 
Table 1: Child labor and School Attendance

Families with at Least One Child Aged 5 to 16 Years Old

\begin{tabular}{|c|c|c|c|c|c|c|c|}
\hline & \multirow[b]{3}{*}{ Child Labor } & \multicolumn{3}{|c|}{ Male Child } & \multicolumn{3}{|c|}{ Female Child } \\
\hline & & \multicolumn{2}{|c|}{ School Attendance } & \multicolumn{4}{|c|}{ School Attendance } \\
\hline & & No & Yes & Total & No & Yes & Total \\
\hline \multirow[t]{3}{*}{ No } & Number & 2,762 & 24,713 & 27,475 & 2522 & 25621 & 28143 \\
\hline & Row \% & 10.05 & 89.95 & 100 & 8.96 & 91.04 & 100 \\
\hline & Column \% & 75.86 & 86.49 & 85.29 & 87.94 & 93.18 & 92.69 \\
\hline \multirow[t]{3}{*}{ Yes } & Number & 879 & 3,859 & 4,738 & 346 & 1874 & 2220 \\
\hline & Row \% & 18.55 & 81.45 & 100 & 15.59 & 84.41 & 100 \\
\hline & Column \% & 24.14 & 13.51 & 14.71 & 12.06 & 6.82 & 7.31 \\
\hline \multirow[t]{3}{*}{ Total } & Number & 3,641 & 28,572 & 32,213 & 2868 & 27495 & 30363 \\
\hline & Row \% & 11.30 & 88.70 & 100 & 9.45 & 90.55 & 100 \\
\hline & Column \% & 100 & 100 & 100 & 100 & 100 & 100 \\
\hline
\end{tabular}


Table 2: Bivariate Probit of Child Labor and School Attendance Families with at Least One Child Aged 5 to 16 Years Old

\begin{tabular}{|c|c|c|c|c|c|c|c|c|}
\hline \multirow[b]{3}{*}{ Independent Variables } & \multicolumn{4}{|c|}{ Male Child } & \multicolumn{4}{|c|}{ Female Child } \\
\hline & \multicolumn{2}{|c|}{ Work } & \multicolumn{2}{|c|}{ School } & \multicolumn{2}{|c|}{ Work } & \multicolumn{2}{|c|}{ School } \\
\hline & Coeff. & $\begin{array}{c}\text { Std. } \\
\text { Erro1 }\end{array}$ & Coeff. & $\begin{array}{r}\text { Std. } \\
\text { Error }\end{array}$ & Coeff. & $\begin{array}{c}\text { Std. } \\
\text { Error }\end{array}$ & Coeff. & $\begin{array}{r}\text { Std. } \\
\text { Error } \\
\end{array}$ \\
\hline First-Born Child & -0.037 & $0.03 \mathrm{C}$ & $-0.075 * *$ & 0.028 & -0.056 & 0.037 & $-0.123 * *$ & 0.032 \\
\hline Last-Born Child & $-0.080 * *$ & $0.03 \mathrm{C}$ & -0.044 & 0.026 & -0.059 & 0.035 & -0.053 & 0.029 \\
\hline Oldest Sibling is Female & -0.027 & 0.028 & $0.069 * *$ & 0.025 & 0.019 & 0.033 & 0.029 & 0.027 \\
\hline Child's Age & $0.293 * *$ & 0.005 & $0.057 * *$ & 0.004 & $0.227 * *$ & 0.005 & $0.084 * *$ & 0.004 \\
\hline Non-White Child & $-0.056 * *$ & 0.023 & 0.036 & 0.021 & $-0.066 * *$ & 0.027 & $0.055^{* *}$ & 0.023 \\
\hline Father's Schooling & $-0.060 * *$ & 0.004 & $0.046^{* *}$ & 0.004 & $-0.030 * *$ & 0.005 & $0.031 * *$ & 0.004 \\
\hline Mother's Schooling & $-0.024 * *$ & 0.004 & $0.057 * *$ & 0.004 & $-0.031 * *$ & 0.005 & $0.069 * *$ & 0.004 \\
\hline Father's Age & 0.001 & 0.002 & 0.002 & 0.002 & -0.001 & 0.002 & -0.001 & 0.002 \\
\hline Mother's Age & $-0.004 *$ & 0.002 & 0.003 & 0.002 & -0.005 & 0.003 & 0.004 & 0.002 \\
\hline Rural & $0.884 * *$ & 0.026 & $-0.115^{* *}$ & 0.023 & $0.624 * *$ & 0.029 & $-0.167 * *$ & 0.025 \\
\hline Number of Children & $0.031 * *$ & 0.008 & $-0.054 * *$ & 0.007 & $0.029 * *$ & 0.009 & $-0.048 * *$ & 0.008 \\
\hline Constant & $-4.446 * *$ & 0.088 & $0.224 * *$ & 0.073 & $-3.986 * *$ & 0.099 & $0.16 C^{*}$ & 0.079 \\
\hline rho & $-0.140 * *$ & 0.018 & & & $-0.138 * *$ & 0.022 & & \\
\hline Log-Likelihood & $-18,768.38$ & & & & $-14,293.09$ & & & \\
\hline Sample Size & 31,948 & & & & 30,117 & & & \\
\hline
\end{tabular}

Note: ** Statistically significant at $1 \%$ level. * Statistically significant at $5 \%$ level.

White's heteroskedastic consistent errors used in all regressions. 
Table 3: Bivariate Probit of Child Labor and School Attendance Families with at Least One Child Aged 5 to 16 Years Old AND Mothers Aged at Least 40 Years Old

\begin{tabular}{|c|c|c|c|c|c|c|c|c|}
\hline \multirow[b]{3}{*}{ Independent Variables } & \multicolumn{4}{|c|}{ Male Child } & \multicolumn{4}{|c|}{ Female Child } \\
\hline & \multicolumn{2}{|c|}{ Work } & \multicolumn{2}{|c|}{ School } & \multicolumn{2}{|c|}{ Work } & \multicolumn{2}{|c|}{ School } \\
\hline & Coeff. & $\begin{array}{c}\text { Std. } \\
\text { Error }\end{array}$ & Coeff. & $\begin{array}{c}\text { Std. } \\
\text { Error }\end{array}$ & Coeff. & $\begin{array}{c}\text { Std. } \\
\text { Error }\end{array}$ & Coeff. & $\begin{array}{r}\text { Std. } \\
\text { Error } \\
\end{array}$ \\
\hline First-Born Child & -0.027 & 0.046 & $-0.120 * *$ & 0.049 & -0.095 & 0.056 & $-0.212 * *$ & 0.059 \\
\hline Last-Born Child & $-0.167 * *$ & 0.040 & -0.032 & 0.042 & $-0.096 *$ & 0.046 & 0.075 & 0.046 \\
\hline Oldest Sibling is Female & 0.004 & 0.037 & $0.102 * *$ & 0.040 & 0.002 & 0.043 & $0.133 * *$ & 0.044 \\
\hline Child's Age & $0.270 * *$ & 0.007 & -0.010 & 0.007 & $0.204 * *$ & 0.008 & $0.029 * *$ & 0.007 \\
\hline Non-White Child & -0.078 & 0.033 & -0.019 & 0.036 & $-0.114 * *$ & 0.038 & 0.045 & 0.039 \\
\hline Father's Schooling & $-0.066 * *$ & 0.006 & $0.046^{* *}$ & 0.007 & $-0.031 * *$ & 0.007 & $0.031 * *$ & 0.007 \\
\hline Mother's Schooling & $-0.030 * *$ & 0.006 & $0.060 * *$ & 0.007 & $-0.038 * *$ & 0.007 & $0.063 * *$ & 0.007 \\
\hline Father's Age & 0.000 & 0.002 & 0.001 & 0.002 & -0.003 & 0.003 & -0.002 & 0.003 \\
\hline Mother's Age & -0.002 & 0.004 & 0.000 & 0.004 & -0.008 & 0.004 & -0.008 & 0.004 \\
\hline Rural & $0.919 * *$ & 0.037 & $-0.096 * *$ & 0.038 & $0.655 * *$ & 0.042 & $-0.208 * *$ & 0.042 \\
\hline Number of Children & 0.006 & 0.011 & $-0.051 * *$ & 0.011 & 0.006 & 0.012 & $-0.032 * *$ & 0.012 \\
\hline Constant & $-4.027 * *$ & 0.178 & $1.164 * *$ & 0.192 & $-3.243 * *$ & 0.206 & $1.235^{* *}$ & 0.197 \\
\hline rho & $-0.172 * *$ & 0.026 & & & $-0.140 * *$ & 0.031 & & \\
\hline Log-Likelihood & -7597.61 & & & & -5771.45 & & & \\
\hline Sample Size & 11,177 & & & & 10,687 & & & \\
\hline
\end{tabular}

Note: ** Statistically significant at $1 \%$ level. * Statistically significant at $5 \%$ level.

White's heteroskedastic consistent errors used in all regressions. 
Table 4: Bivariate Probit of Child Labor and School Attendance

Three-Children Families With At Least One Child Aged 5 to 16 Years Old

\begin{tabular}{|c|c|c|c|c|c|c|c|c|}
\hline \multirow[b]{3}{*}{ Independent Variables } & \multicolumn{4}{|c|}{ Male Child } & \multicolumn{4}{|c|}{ Female Child } \\
\hline & \multicolumn{2}{|c|}{ Work } & \multicolumn{2}{|c|}{ School } & \multicolumn{2}{|c|}{ Work } & \multicolumn{2}{|c|}{ School } \\
\hline & Coeff. & $\begin{array}{l}\text { Std. } \\
\text { Error }\end{array}$ & Coeff. & $\begin{array}{l}\text { Std. } \\
\text { Error }\end{array}$ & Coeff. & $\begin{array}{l}\text { Std. } \\
\text { Error }\end{array}$ & Coeff. & $\begin{array}{l}\text { Std. } \\
\text { Error }\end{array}$ \\
\hline First Born Child & -0.064 & 0.056 & -0.058 & 0.055 & -0.049 & 0.070 & $-0.123 *$ & 0.063 \\
\hline Last Born Child & $-0.116 * *$ & 0.056 & 0.065 & 0.053 & -0.006 & 0.068 & 0.036 & 0.060 \\
\hline Oldest Sibling is Female & 0.031 & 0.052 & -0.007 & 0.049 & 0.095 & 0.064 & 0.020 & 0.055 \\
\hline Child Age & $0.298 * *$ & 0.010 & $0.069 * *$ & 0.008 & $0.236^{* *}$ & 0.011 & $0.117 * *$ & 0.010 \\
\hline Non-White Child & -0.042 & 0.044 & 0.024 & 0.041 & -0.007 & 0.052 & -0.020 & 0.047 \\
\hline Father's Schooling & $-0.062 * *$ & 0.008 & $0.046^{* *}$ & 0.007 & $-0.030 * *$ & 0.009 & $0.024 * *$ & 0.008 \\
\hline Mother's Schooling & $-0.022 * *$ & 0.008 & $0.059^{* *}$ & 0.007 & $-0.030 * *$ & 0.009 & $0.064 * *$ & 0.008 \\
\hline Father's Age & 0.000 & 0.003 & -0.003 & 0.003 & 0.001 & 0.004 & 0.000 & 0.004 \\
\hline Mother's Age & -0.001 & 0.005 & $0.009 * *$ & 0.004 & -0.010 & 0.006 & -0.006 & 0.005 \\
\hline Rural & $0.839 * *$ & 0.051 & $-0.079 *$ & 0.047 & $0.565 * *$ & 0.060 & $-0.199 * *$ & 0.053 \\
\hline Constant & $-4.489 * *$ & 0.162 & -0.065 & 0.137 & $-3.969 * *$ & 0.184 & 0.157 & 0.153 \\
\hline Rho & -0.078 & 0.037 & & & -0.187 & 0.045 & & \\
\hline Log-Likelihood & -4718 & & & & -3296 & & & \\
\hline Sample Size & 8,628 & & & & 8,006 & & & \\
\hline
\end{tabular}

Note: ** Statistically significant at $1 \%$ level. * Statistically significant at $5 \%$ level.

White's heteroskedastic consistent errors used in all regressions. 
Table 5: Bivariate Probit of Child Labor and School Attendance

Three-Children Families with at Least One Child Aged 5 to 16 Years Old AND Mothers Aged 40 or above

\begin{tabular}{|c|c|c|c|c|c|c|c|c|}
\hline \multirow[b]{3}{*}{ Independent Variables } & \multicolumn{4}{|c|}{ Male Child } & \multicolumn{4}{|c|}{ Female Child } \\
\hline & \multicolumn{2}{|c|}{ Work } & \multicolumn{2}{|c|}{ School } & \multicolumn{2}{|c|}{ Work } & \multicolumn{2}{|c|}{ School } \\
\hline & Coeff. & $\begin{array}{r}\text { Std. } \\
\text { Error }\end{array}$ & Coeff. & $\begin{array}{r}\text { Std. } \\
\text { Error }\end{array}$ & Coeff. & $\begin{array}{r}\text { Std. } \\
\text { Error }\end{array}$ & Coeff. & $\begin{array}{r}\text { Std. } \\
\text { Error }\end{array}$ \\
\hline First-Born Child & -0.059 & 0.095 & -0.065 & 0.114 & -0.102 & 0.120 & -0.169 & 0.138 \\
\hline Last-Born Child & $-0.212 * *$ & 0.075 & 0.028 & 0.087 & -0.003 & 0.089 & 0.078 & 0.102 \\
\hline Oldest Sibling is Female & 0.085 & 0.073 & 0.016 & 0.082 & 0.064 & 0.088 & 0.125 & 0.096 \\
\hline Child's Age & $0.281 * *$ & 0.015 & -0.016 & 0.016 & $0.234 * *$ & 0.018 & 0.022 & 0.017 \\
\hline Non-White Child & -0.056 & 0.067 & -0.106 & 0.077 & -0.014 & 0.080 & -0.027 & 0.087 \\
\hline Father's Schooling & $-0.073 * *$ & 0.011 & $0.041 * *$ & 0.013 & $-0.035 * *$ & 0.013 & $0.031 *$ & 0.014 \\
\hline Mother's Schooling & -0.020 & 0.011 & $0.056^{* *}$ & 0.013 & $-0.038 * *$ & 0.014 & $0.058 * *$ & 0.015 \\
\hline Father's Age & 0.002 & 0.005 & -0.004 & 0.005 & -0.002 & 0.006 & -0.003 & 0.006 \\
\hline Mother's Age & 0.005 & 0.008 & 0.000 & 0.009 & $-0.028 * *$ & 0.010 & -0.014 & 0.008 \\
\hline Rural & $0.882 * *$ & 0.081 & -0.108 & 0.087 & $0.682 * *$ & 0.095 & $-0.328 * *$ & 0.099 \\
\hline Constant & $-4.588 * *$ & 0.369 & $1.435^{* *}$ & 0.388 & $-2.926 * *$ & 0.452 & $1.702 * *$ & 0.386 \\
\hline rho & $-0.146 * *$ & 0.058 & & & $-0.221 * *$ & 0.067 & & \\
\hline Log-Likelihood & -1679.60 & & & & -1140.30 & & & \\
\hline Sample Size & 2775 & & & & 2523 & & & \\
\hline
\end{tabular}

Note: ** Statistically significant at $1 \%$ level. * Statistically significant at $5 \%$ level.

White's heteroskedastic consistent errors used in all regressions. 
Table 6: Bivariate Probit of Child Labor and School Attendance on Age Difference Families with at Least One Child Aged 5 to 16 Years Old

\begin{tabular}{|c|c|c|c|c|c|c|c|c|}
\hline \multirow[b]{3}{*}{ Independent Variables } & \multicolumn{4}{|c|}{ Male Child } & \multicolumn{4}{|c|}{ Female Child } \\
\hline & \multicolumn{2}{|l|}{ Work } & \multicolumn{2}{|c|}{ School } & \multicolumn{2}{|l|}{ Work } & \multicolumn{2}{|c|}{ School } \\
\hline & Coeff. & $\begin{array}{c}\text { Std. } \\
\text { Error }\end{array}$ & Coeff. & $\begin{array}{c}\text { Std. } \\
\text { Error }\end{array}$ & Coeff. & $\begin{array}{c}\text { Std. } \\
\text { Error }\end{array}$ & Coeff. & $\begin{array}{r}\text { Std. } \\
\text { Error }\end{array}$ \\
\hline Age Diff. w/ First-Born & -0.008 & 0.004 & 0.007 & 0.004 & -0.006 & 0.005 & 0.006 & 0.004 \\
\hline Age Diff. w/ Last-Born & $0.008 *$ & 0.004 & $-0.014 * *$ & 0.004 & 0.006 & 0.004 & $-0.023 * *$ & 0.004 \\
\hline Oldest Sibling is Female & -0.005 & 0.026 & $0.069 * *$ & 0.023 & -0.022 & 0.030 & 0.024 & 0.025 \\
\hline Child's Age & $0.287 * *$ & 0.005 & $0.067 * *$ & 0.004 & $0.222 * *$ & 0.006 & $0.098 * *$ & 0.005 \\
\hline Non-White Child & $-0.055 *$ & 0.023 & 0.036 & 0.021 & $-0.067 * *$ & 0.027 & $0.055 * *$ & 0.023 \\
\hline Father's Schooling & $-0.059 * *$ & 0.004 & $0.046 * *$ & 0.004 & $-0.030 * *$ & 0.005 & $0.031 * *$ & 0.004 \\
\hline Mother's Schooling & $-0.024 * *$ & 0.004 & $0.057 * *$ & 0.004 & $-0.031 * *$ & 0.005 & $0.069 * *$ & 0.004 \\
\hline Father's Age & 0.002 & 0.002 & 0.001 & 0.002 & 0.000 & 0.002 & -0.002 & 0.002 \\
\hline Mother's Age & -0.002 & 0.002 & -0.001 & 0.002 & -0.003 & 0.003 & -0.001 & 0.002 \\
\hline Rural & $0.880 * *$ & 0.026 & $-0.109 * *$ & 0.023 & $0.621 * *$ & 0.029 & $-0.162 * *$ & 0.025 \\
\hline Number of Children & $0.039 * *$ & 0.009 & $-0.034 * *$ & 0.009 & $0.036 * *$ & 0.010 & -0.016 & 0.009 \\
\hline Constant & $-4.570 * *$ & 0.082 & $0.207 * *$ & 0.067 & $-4.068 * *$ & 0.096 & 0.119 & 0.077 \\
\hline rho & $-0.138 * *$ & 0.018 & & & $-0.133 * *$ & 0.022 & & \\
\hline Log-Likelihood & $-18,757.60$ & & & & $-14,280.02$ & & & \\
\hline Sample Size & 31,948 & & & & 30,117 & & & \\
\hline
\end{tabular}

Note: ** Statistically significant at $1 \%$ level. * Statistically significant at $5 \%$ level.

White's heteroskedastic consistent errors used in all regressions. 
Table 7: Bivariate Probit of Child Labor and School Attendance Families With At Least One Child Aged 5 to 16 Years Old

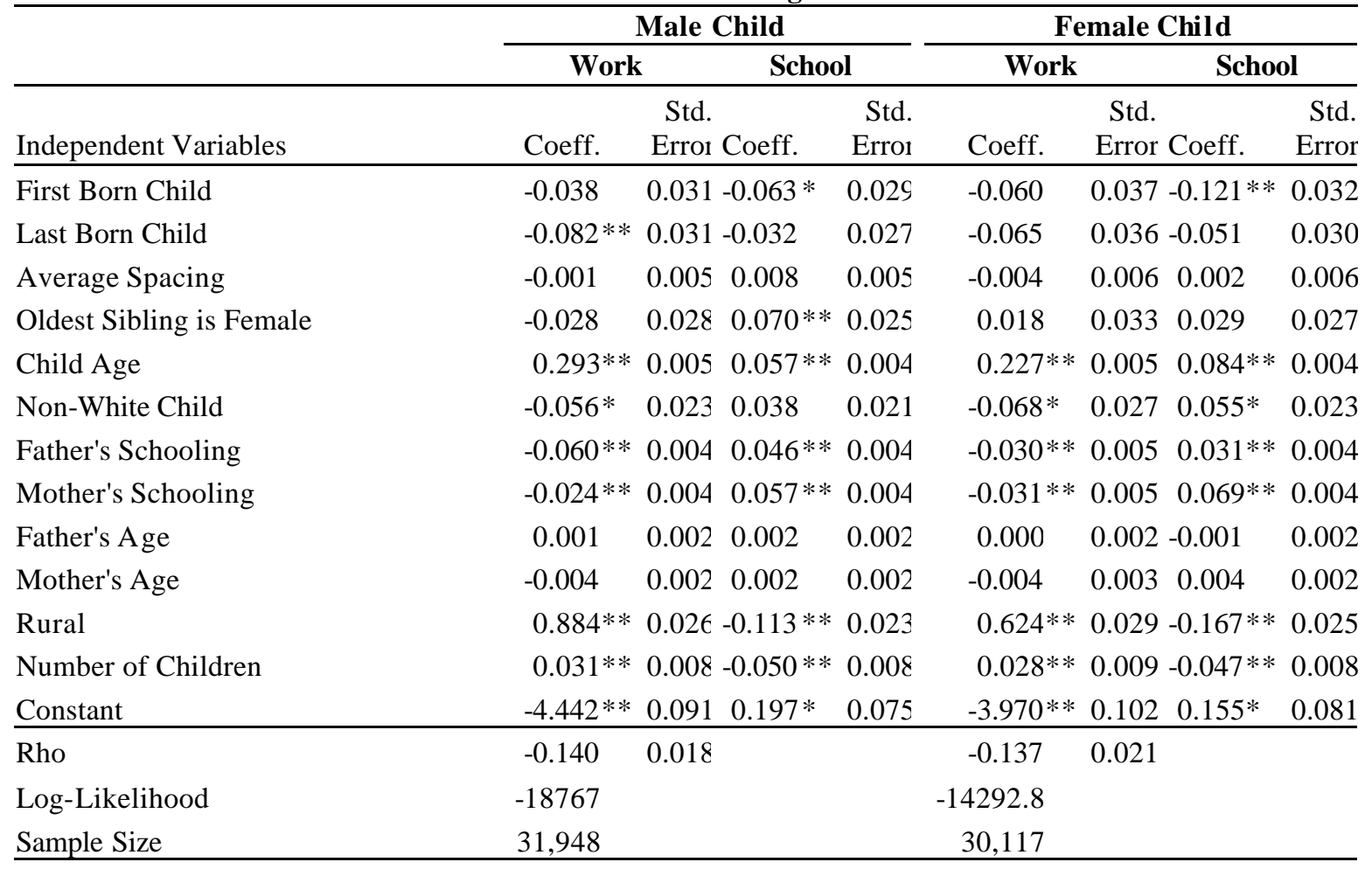

Note: ** Statistically significant at $1 \%$ level. * Statistically significant at $5 \%$ level.

White's heteroskedastic consistent errors used in all regressions. 
Table A1: Unweighted Basic Statistics

\begin{tabular}{|c|c|c|c|c|c|}
\hline Variables & Obs & Mean & Std. Error & Min & Max \\
\hline & \multicolumn{5}{|c|}{ Male Children } \\
\hline Child's Age & 32,213 & 10.530 & 3.436 & 5 & $\overline{16}$ \\
\hline Non-White Child & 32,210 & 0.518 & 0.500 & 0 & 1 \\
\hline School & 32,213 & 0.887 & 0.317 & 0 & 1 \\
\hline Work & 32,213 & 0.147 & 0.354 & 0 & 1 \\
\hline Rural & 32,213 & 0.236 & 0.425 & 0 & 1 \\
\hline Number of Siblings & 32,213 & 3.171 & 1.661 & 1 & 13 \\
\hline First-Born Child & 32,213 & 0.401 & 0.490 & 0 & 1 \\
\hline Last-Born Child & 32,213 & 0.391 & 0.488 & 0 & 1 \\
\hline Age Diff. w/ First-Born & 32,213 & 3.347 & 4.108 & 0 & 40 \\
\hline Age Diff. w/ Last-Born & 32,213 & 3.285 & 3.650 & 0 & 16 \\
\hline Father's Age & 32,213 & 41.559 & 9.041 & 20 & 94 \\
\hline Father's Schooling & 32,093 & 5.205 & 4.370 & 0 & 15 \\
\hline Mother's Age & 32,213 & 37.264 & 7.601 & 20 & 97 \\
\hline \multirow[t]{2}{*}{ Mother's Schooling } & 32,054 & 5.426 & 4.212 & 0 & 15 \\
\hline & \multicolumn{5}{|c|}{ Female Children } \\
\hline Child's Age & 30,365 & 10.493 & 3.408 & 5 & $\overline{16}$ \\
\hline Non-White Child & 30,364 & 0.504 & 0.500 & 0 & 1 \\
\hline School & 30,364 & 0.906 & 0.292 & 0 & 1 \\
\hline Work & 30,364 & 0.073 & 0.260 & 0 & 1 \\
\hline Rural & 30,365 & 0.230 & 0.421 & 0 & 1 \\
\hline Number of Siblings & 30,365 & 3.207 & 1.715 & 1 & 13 \\
\hline First-Born Child & 30,365 & 0.397 & 0.489 & 0 & 1 \\
\hline Last-Born Child & 30,365 & 0.396 & 0.489 & 0 & 1 \\
\hline Age Diff. w/ First-Born & 30,365 & 3.453 & 4.211 & 0 & 41 \\
\hline Age Diff. w/ Last-Born & 30,365 & 3.243 & 3.61 & 0 & 16 \\
\hline Father's Age & 30,365 & 41.581 & 9.031 & 20 & 101 \\
\hline Father's Schooling & 30,257 & 5.239 & 4.362 & 0 & 15 \\
\hline Mother's Age & 30,365 & 37.316 & 7.615 & 20 & 92 \\
\hline Mother's Schooling & 30,205 & 5.437 & 4.195 & 0 & 15 \\
\hline
\end{tabular}


Table A2: Bivariate Probit of Child Labor and School Attendance on Birth Order and Age Difference

\begin{tabular}{|c|c|c|c|c|c|c|c|c|}
\hline \multicolumn{9}{|c|}{ Families with at Least One Child Aged 5 to 16 Years Old } \\
\hline & \multicolumn{4}{|c|}{$\begin{array}{l}\text { Male Child } \\
\end{array}$} & \multicolumn{4}{|c|}{ Female Child } \\
\hline & \multicolumn{2}{|c|}{ Work } & \multicolumn{2}{|c|}{ School } & \multicolumn{2}{|c|}{ Work } & \multicolumn{2}{|c|}{ School } \\
\hline Independent Variables & Coeff. & $\begin{array}{r}\text { Std. } \\
\text { Error } \\
\end{array}$ & Coeff. & $\begin{array}{r}\text { Std. } \\
\text { Error } \\
\end{array}$ & Coeff. & $\begin{array}{r}\text { Std. } \\
\text { Error } \\
\end{array}$ & Coeff. & $\begin{array}{r}\text { Std. } \\
\text { Error } \\
\end{array}$ \\
\hline First-Born Child & $-0.095 * *$ & 0.034 & -0.012 & 0.031 & $-0.095 * *$ & 0.040 & -0.060 & 0.034 \\
\hline Last-Born Child & -0.029 & 0.034 & $-0.141 * *$ & 0.032 & -0.014 & 0.040 & $-0.198 * *$ & 0.036 \\
\hline Age Diff. w/ First-Born & $-0.013 * *$ & 0.005 & $0.009^{*}$ & 0.004 & $-0.010^{*}$ & 0.005 & 0.008 & 0.004 \\
\hline Age Diff. w/ Last-Born & $0.009 *$ & 0.004 & $-0.024 * *$ & 0.005 & 0.008 & 0.005 & $-0.036 * *$ & 0.005 \\
\hline Oldest Sibling is Female & -0.034 & 0.028 & $0.073 * *$ & 0.025 & 0.012 & 0.033 & 0.034 & 0.027 \\
\hline Child's Age & $0.286 * *$ & 0.005 & $0.068 * *$ & 0.004 & $0.221 * *$ & 0.006 & $0.099 * *$ & 0.005 \\
\hline Non-White Child & $-0.057 * *$ & 0.023 & 0.032 & 0.021 & $-0.068 * *$ & 0.027 & $0.052^{*}$ & 0.023 \\
\hline Father's Schooling & $-0.059 * *$ & 0.004 & $0.046^{* *}$ & 0.004 & $-0.030 * *$ & 0.005 & $0.031 * *$ & 0.004 \\
\hline Mother's Schooling & $-0.024 * *$ & 0.004 & $0.057 * *$ & 0.004 & $-0.031 * *$ & 0.005 & $0.069 * *$ & 0.004 \\
\hline Father's Age & 0.002 & 0.002 & 0.001 & 0.002 & 0.000 & 0.002 & -0.001 & 0.002 \\
\hline Mother's Age & -0.001 & 0.002 & 0.000 & 0.002 & -0.002 & 0.003 & $0.00 \mathrm{C}$ & 0.002 \\
\hline Rural & $0.880 * *$ & 0.026 & $-0.110 * *$ & 0.023 & $0.621 * *$ & 0.029 & $-0.163 * *$ & 0.025 \\
\hline Number of Children & $0.030 * *$ & 0.010 & $-0.043 * *$ & 0.009 & $0.030 * *$ & 0.011 & $-0.031 * *$ & 0.010 \\
\hline Constant & $-4.481 * *$ & 0.088 & $0.284 * *$ & 0.074 & $-4.026 * *$ & 0.100 & $0.249 * *$ & 0.080 \\
\hline rho & $-0.137 * *$ & 0.018 & & & $-0.133 * *$ & 0.021 & & \\
\hline Log-Likelihood & $-18,742.59$ & & & & $-14,259.35$ & & & \\
\hline Sample Size & 31,948 & & & & 30,117 & & & \\
\hline
\end{tabular}

Note: ** Statistically significant at $1 \%$ level. * Statistically significant at $5 \%$ level.

White's heteroskedastic consistent errors used in all regressions. 
Figure 1: Predicted Probability of Working for 15 Year-Old Males from All-Male Three Children Families

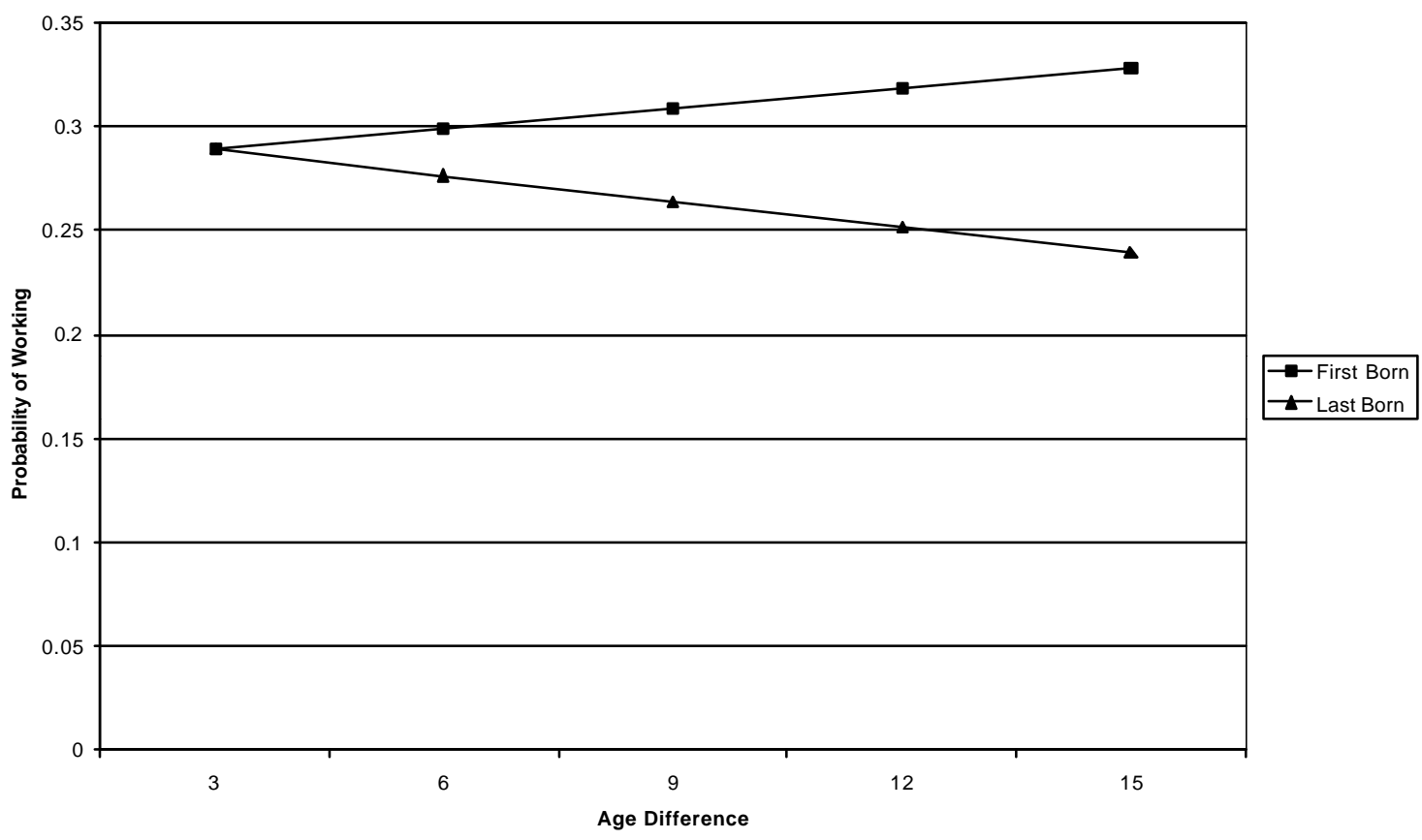

Figure 2: Predicted Probability of Attending School for 15 Year-Old Males from All-Male Three Children Families

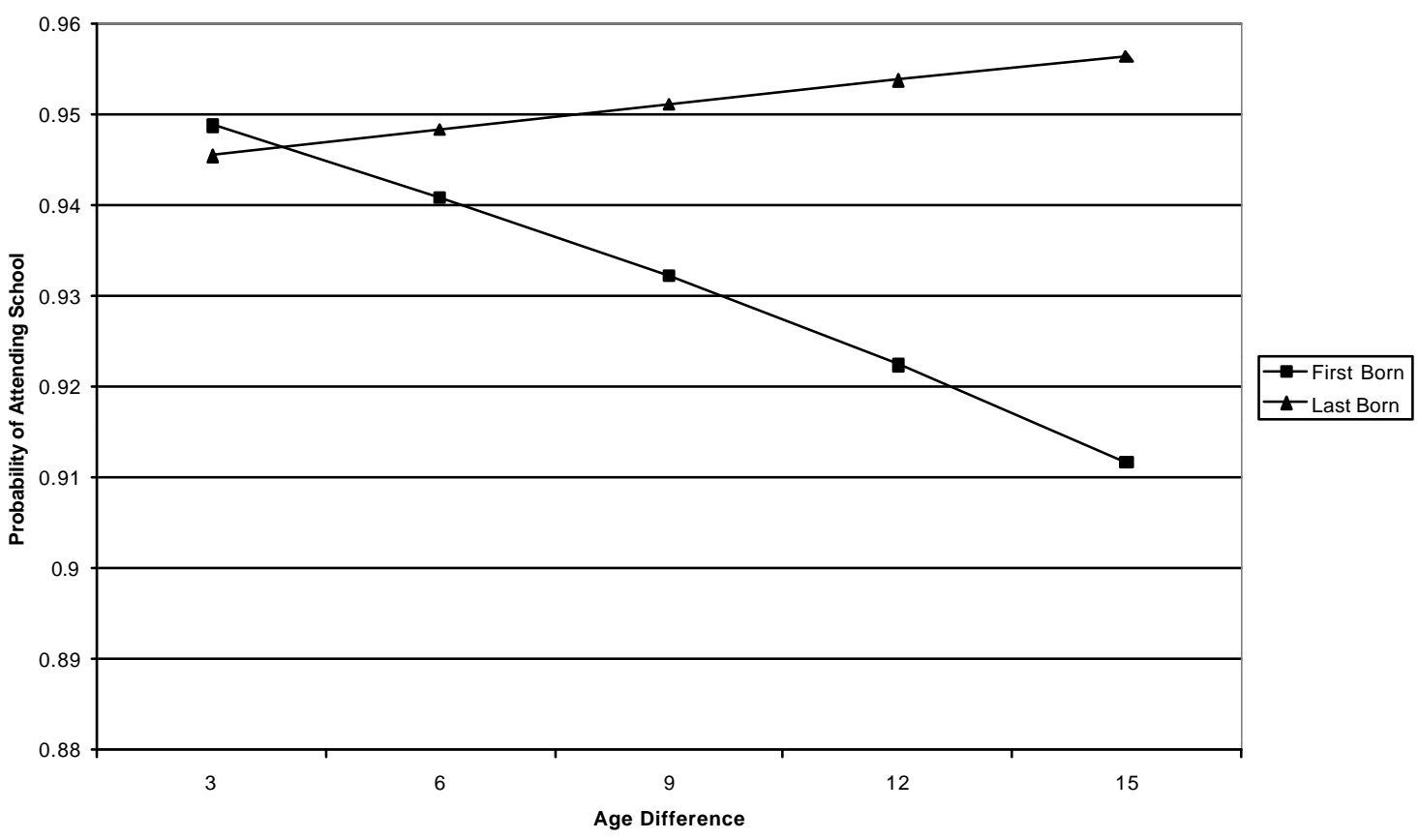


Figure 3: Predicted Probability of Working for 15 Year-Old Females from All-Female Three Children Families

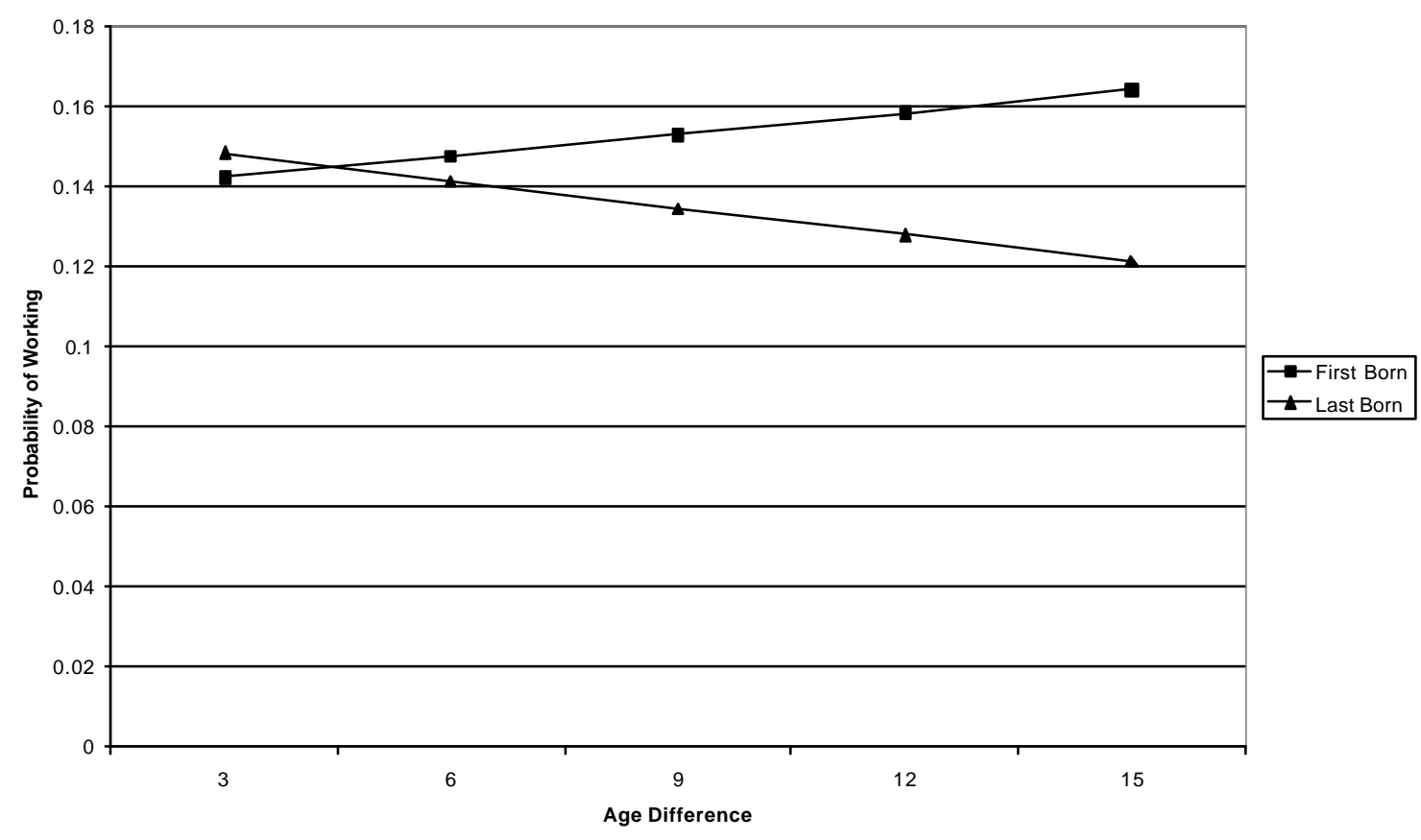

Figure 4: Predicted Probabilty of Attending School for 15 Year-Old Females from All-Female Three Children Families

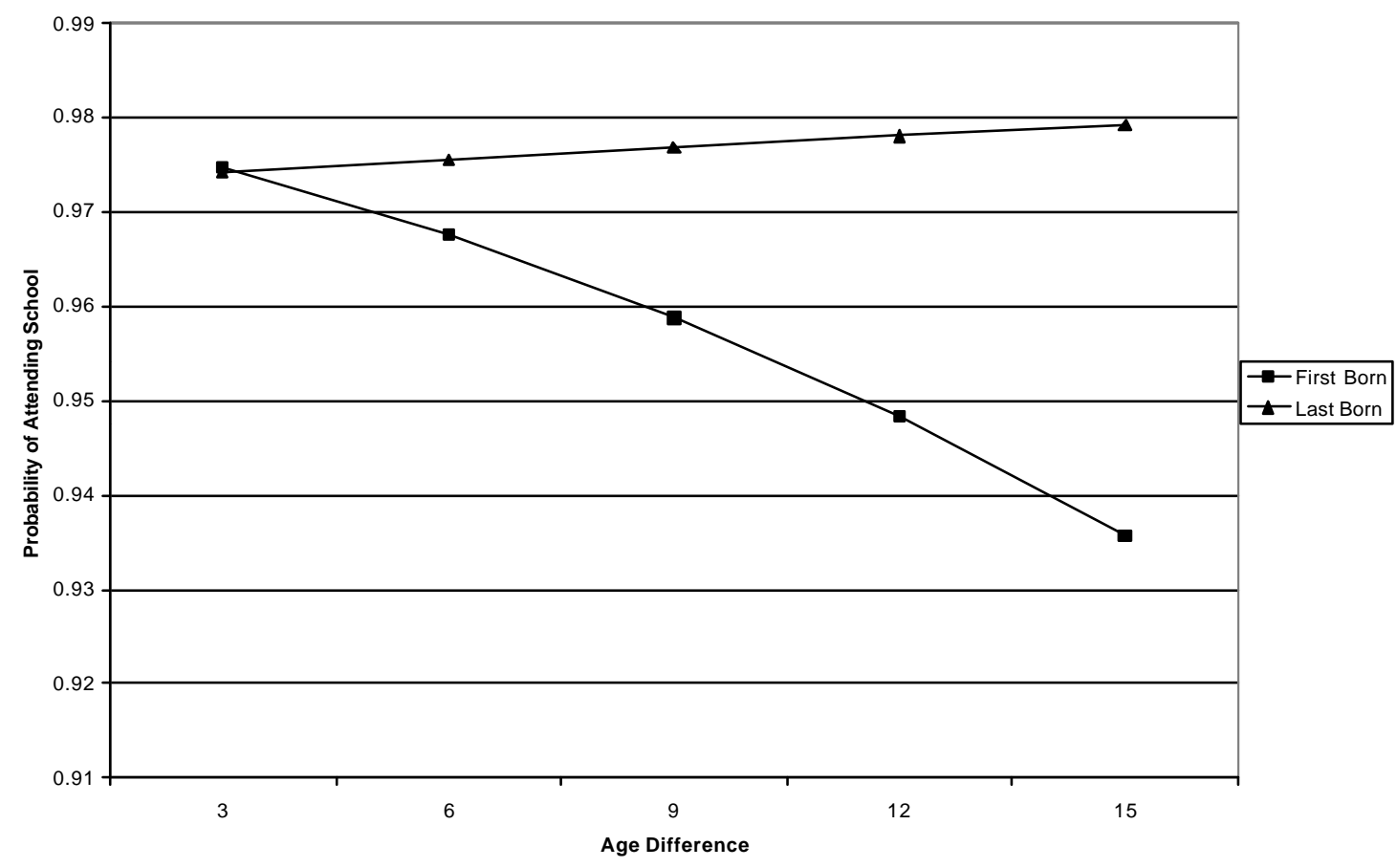

